\title{
Ethnomedicine Study of Tengger People of Ngadas Village in Malang, East Java, Indonesia: In Search of Antimicrobial Plants
}

\author{
Alvan F. Shalas*, Uswatun Khasanah, Oktavia Rahayu Adianingsih, Kevin Rexy Raharjaa, Nadia Khansa', Rahardian Akbar Maula, \\ Nuke Candra Destian, Siska Wahyu Lestari \\ Department of Pharmacy, Faculty of Medicine, Universitas Brawijaya, INDONESIA.
}

\begin{abstract}
Background: New antimicrobial substances are increasingly needed to face issues of antibacterial resistance, and plants are one of the potential sources of these substances. The Tengger people of East Java, Indonesia empirically possess the knowledge of medicinal plants that need to be documented and assessed further for their potencies. Objectives: This study aimed to find plants with the potency of antimicrobial activity, by quantifying ethnomedicinal data from The Tengger people. Materials and Methods: In this study, snowball sampling was chosen as the sampling method. Information about medicinal plants was obtained by interview with a semi-structured questionnaire, and four indices namely: ethnobotanical richness, use-value index, fidelity level, and knowledge value index were used for quantifying the information gathered from the respondents. Results: The results showed that four plants had prominent values of indices, which were adas (Foeniculum vulgare Mill.), jambu wer (Prunus persica (L.) Batsch), sempretan (Eupatorium sp.), and kayu ampet (Astronia
\end{abstract}

macrophylla L.). Those four plants were recognized by The Tengger people for their medicinal properties, which were anti-diarrhea (jambu wer and sempretan), cough reliever (adas), and wound remedies (sempretan). Conclusion: The plants had the potency to be explored further for their antimicrobial activity. Further exploration is needed to find new active compounds responsible for antimicrobial activity.

Key words: Antimicrobial Plants, Ethnomedicine, Ethnopharmacy, Tengger, Indigenous, Indonesia.

Correspondence

Alvan F. Shalas

Department of Pharmacy, Faculty of Medicine, Universitas Brawijaya, INDONESIA.

Email: alvanshalas@gmail.com

DOI: 10.5530/jyp.2021.13.22

\section{INTRODUCTION}

The usage of plants known as remedies by particular ethnic takes an important part in drug discovery. Approximately $80 \%$ of defined structure compounds used globally as medicine have had an ethnomedicinal use related to the current use of the active parts of the plants. ${ }^{1}$ Recently due to increasing demands of modern lifestyle, accompanied by unplanned development programs of rural areas, has put the traditional knowledge of medicinal plants in the endangered state. Ethnomedicine/ ethnopharmacy study is an important strategy to achieve recovery of the knowledge, which is being linked to the conservation of biodiversity, the discovery of new medicines, and the bettering of the quality of life of poor rural communities. ${ }^{2}$

Indonesia has a great potential to become one of the global main sources of ethnomedicinal-based remedies. Indonesia is a home for approximately 1300 ethnic groups, with diversity in cultural identity, as well as traditional knowledge of healing and medication, with a total number of known higher plant species is over 23,975 species. ${ }^{3,4}$ Nevertheless, lacking documentation on traditional knowledge of medicinal plants makes this enormous resources less meaningful, whereas the challenge of biopiracy and patenting indigenous knowledge are more increasing. Therefore the necessity of documentation of such knowledge becomes crucial regarding the situation. ${ }^{5-7}$

Tengger people is one of the indigenous ethnic of Java Island, Indonesia. Since the fallen of the Majapahit Kingdom, they isolated themselves and prefer to live in their own environment. ${ }^{8}$ Indigenous people of Tengger occupied mountainous areas of today's Bromo Tengger Semeru National Park (BTSNP). In the current time, they reside spread into four districts (Kabupaten) of East Java, which are Lumajang, Pasuruan, Probolinggo, and Malang. Ngadas Village in subdistrict (Kecamatan)
Poncokusumo, Kabupaten Malang is one of the villages inhabited by the people of Tengger. Even right now it is the only village in Kabupaten Malang that the majority of the population are Tengger people and the one with the most rapid growth of tourism as well. Farming used to be the main livelihood of Tengger people in Ngadas, alongside their traditional way of life. ${ }^{9}$ But then increasing tourism due to breathtaking panoramas around the Bromo Mountain, triggers the alteration of the lifestyle of Tengger people toward modernization, threatening their local knowledge conservation.

There are 181 species, belonging to 150 generas and 66 families were reported by Batoro and Siswanto to be used by Tengger people for their healing properties. The diseases that were claimed to be curable by those medicinal plants varied in a great range, from itch and cold to hypertension and diabetes mellitus. ${ }^{10}$ Nonetheless, this precious information of medicinal plants cannot provide us the value of potency of the plants, due to the lack of indexing used in the research. Indices are empowered in social-related research such as ethnomedicine, to deepen the values of the obtained data by quantifying the use of plants and show their importance in the prevailing culture. ${ }^{11}$

This research aims to quantify the medicinal use of plants, known by the Tengger people of Ngadas Village, in Kecamatan Poncokusumo, Kabupaten Malang, specifically for indications that related to infectious diseases. This study is a part of efforts to find new lead compounds for the antimicrobial agent. The expected outcome of this study would not only increase our knowledge about medicinal plants used by the people of Tengger in Ngadas Village but would also leads to the discovery of a new antimicrobial lead compound that may be available for future research. 


\section{MATERIALS AND METHODS}

\section{The Research Site}

Ngadas is the highest village in Java, which is located in the area of Bromo Tengger Semeru National Park (BTSNP), with an altitude of 2200 meters above sea level and an area of approximately 395 hectares. This village is located about 24 kilometers from the center of the Kecamatan Poncokusumo or about 45 kilometers east of the city of Malang. Geographically, Ngadas is located at coordinates between $112^{\circ} 53^{\prime} 50^{\prime \prime}$ $112^{\circ} 55^{\prime} 10^{\prime \prime}$ east longitude, and between $07^{\circ} 59^{\prime} 40^{\prime \prime}$ - 07058'20" south latitude. The location map of the research site can be seen in Figure 1.

The soil profile of Ngadas consists of dust, sand, and clay which is a type of regosol and cytosol soil, an important factor in the vegetation distribution. In the dry season, surface water is difficult to obtain because of a radical drainage pattern. This is because rainwater seeps through the soil and mountain rocks. In the rainy season, river water flows (does not overflow), and some are stored in the lake (Ranu).

\section{Plants}

Plants that information was taken in this study were selected based on the preliminary field survey combined with literature review results. The field survey was conducted for two weeks, together with the period of key informant identification. The authors have screened the medicinal plants data claimed to be used by the Tengger people by the correlation with the antimicrobial properties, according to the indications that were mentioned. The screening resulted in four kinds of indications that related to antimicrobial properties, which were anti-diarrhea, wound remedy, toothache remedy, and cough reliever. There were 32 species of plants included in these classifications. Some of the plants were mentioned for more than one indication, which are calingan, pulosari, and sempretan. The plants explored in the research are listed in Table 1. The plant determination was done by the Indonesian Institute of Sciences (LIPI), Kebun Raya Purwodadi (Determination Letter No. 1140/IPH.06/ HM/IX/2019).

\section{Documentation of Plants Information}

The Snowball technique was selected as the sampling method. The key informant was identified through the recognition by the authorities, both traditional leader (dukun adat) and head of local government (Kepala Desa). The respondents then appointed by the key informant, based on

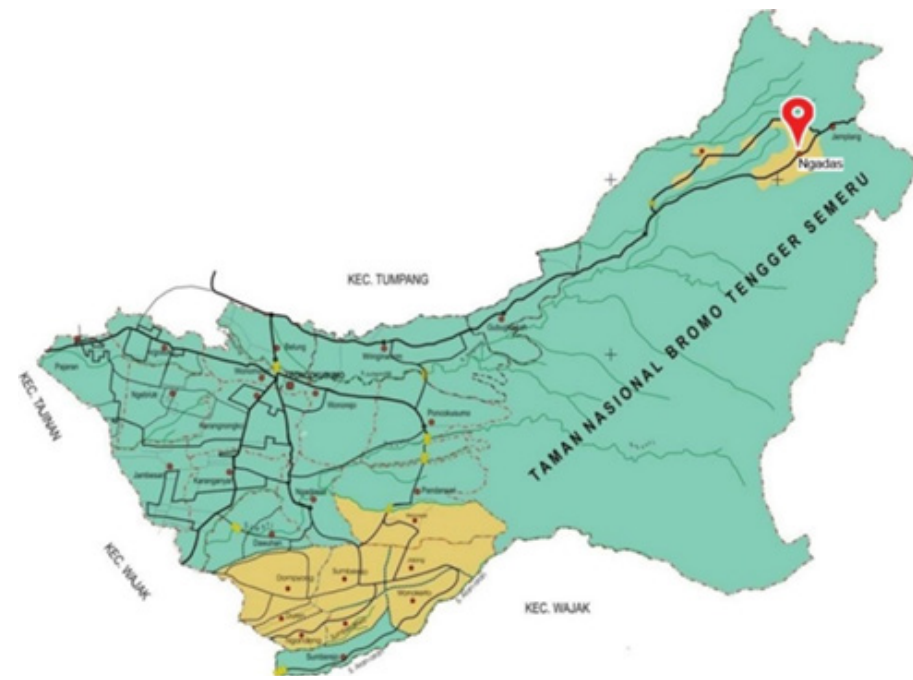

Figure 1: A map showing the research site at Ngadas, situated at Bromo Tengger Semeru National Park, East Java, Indonesia. ${ }^{12}$ his recognition of people possessing traditional knowledge of medicinal plants. These respondents then appointed other respondents through the same recognition process. The number of respondents obtained from the snowball sampling method was not restricted. It was considered sufficient when there were no more new respondents mentioned by the previous respondents.

Respondent's willingness and approval for their involvement in the research was an absolute requirement. Therefore informed consent must be understood prior to the interview and other processes in the research. The ethical clearance for the research was issued by The Ethical Commission for Health Research of Faculty of Medicine, Brawijaya University, through issue No. 56/EC/KEPK/03/2018. A semi-structured questionnaire and open interview were used to collect information about the plants. The following information was collected during the interview: knowledge of the plants; local name; medicinal use; part of the plants used as medicine; preparation and route of administration; regimentation; and economical value of the plants. A total of 14 respondents were interviewed to collect the information needed.

\section{Literature survey for supporting claims}

Literature surveys of published journal papers were accessed through Google Scholar, PubMed, and Scopus. The claims of therapy mentioned by respondents were validated based on there being any antibacterial laboratory result of each plant.

\section{Data Analysis}

Data obtained from this study were then analyzed by indices to assess the potency of the plants quantitatively. The assessment is based on the community reliability of the information. We used four indices namely: Ethnobotanical Richness (ER); Use Value Index (UVI); Fidelity Level (FL); and Knowledge Value Index (KVI). During the study, we found that all of the respondents were possessing knowledge of medicinal plants with lacking medication practices so that we applied modification for the calculation of the indices.

a. Ethnobotanical Richness (ER)

ER is a quantification of ethnic-specific usage of the plant. ${ }^{13}$ ER value was obtained using the formula:

$E R=\frac{E r}{n}$

'Er' reflects the number of respondents knowing the plant for its medicinal property, while ' $n$ ' represents the total number of respondents. b. Use Value Index (UVI)

UVI is a measure of the plant's importance level., ${ }^{2,14}$ UVI was calculated using the formula as below:

$U V I=\frac{\sum U}{n s}$

Where ' $U$ ' is the number of uses of the plant mentioned by the respondents, and ' $n s$ ' is a number of respondents knowing and applying the medicinal use of the plant.

c. Fidelity Level (FL)

FL was calculated to determine the percentage of respondents who claim the use of the plant for the same major medicinal purpose. ${ }^{15} \mathrm{FL}$ was calculated using the formula:

$F L=\frac{N p \times 100}{n}$

' $\mathrm{Np}$ ' is a number of respondents claiming specific medicinal use of the plant, and ' $n$ ' is a number of respondents knowing or applying the plant for any medicinal purpose.

d. Knowledge Value Index (KVI) 
KVI determines the novelty level in local names not yet documented and further appraises the continued medicinal use of the plant. ${ }^{16} \mathrm{KVI}$ was calculated as below:

$K V I=\frac{\Sigma A}{n}$

'A' is the number of respondents who knows the plant without knowing its botanical name, and ' $n$ ' is the total number of respondents

\section{RESULTS}

\section{Demographic Data}

From the preliminary survey, we found that there was a total of 14 respondents from the village possessing information on medicinal plants.
As many as 2 of them were recognized as the key informants (ST and TB) by both Dukun Adat and Kepala Desa. Most of the respondents were farmers (71.4\%), while the other $38.6 \%$ were varied in the professions which were tour guide, trader, teacher, and pensionary of forestry department (Figure 2).

All respondents were male, with ages varies between 35 to 83 years old. Two respondents had never been in any education, 7 respondents have finished their education at elementary school, 2 respondents at junior high school, 1 respondent at senior high school, and only 2 respondents went to higher educational level (Figure 3). It is interesting that the majority of the respondents were the elderly, some of them were middle-aged, and there was no younger generation recognized to possess knowledge of medicinal plants. Related to the knowledge conservation

Table 1: The plants to be analysed.

\begin{tabular}{|c|c|c|c|}
\hline No & Indication & Plants Local Name & Species \\
\hline 1. & Anti Diarrhea & Cemara & Cassuarina equisetifolia J.R. and G. Forst \\
\hline 2. & & Calingan & Rubus alpestris Hook.f. \\
\hline 3. & & Jambu Wer & Prunus persica (L.) Batsch \\
\hline 4. & & Jambu Jawa & Psidium guajava L. \\
\hline 5. & & Manggis & Garcinia mangostana L. \\
\hline 6. & & Pulosari & Alyxia reinwardtii \\
\hline 7. & & Petungan & Equisetum ramosissimum (Roxb.ex Vaucher) Hauke \\
\hline 8. & & Kayu Ampet & Astronia macrophylla $\mathrm{L}$. \\
\hline 9. & Wound remedy & Suri Pandak & Plantago mayor L. \\
\hline 10. & & Sempretan & Eupatorium sp. \\
\hline 11. & & Klandingan & Albizia lophanta (Wild.) Bth. \\
\hline 12. & & Ketiu & Sonchus asper (L.) Hill \\
\hline 13. & & Kayu Kulit & Cinnamomum burmanni Ness ex BI. \\
\hline 14. & & Menjari & Sonchus oleraceus L. \\
\hline 15. & & Alang-alang & Imperarata cylindrica (Ness) C.E. \\
\hline 16. & & Binahong & Anredera cordifolia (Tenore) Stenn. \\
\hline 17. & & Grinting & Cynodon dactylon (L.) Pers \\
\hline 18. & & Jamur Impes & Calvatia bovista (L.) Van Overeem \\
\hline 19. & Toothache remedy & Sirih & Piper betle L. \\
\hline 20. & & Semboja & Euphorbia pulcherrima Willd.ex Klotzsch \\
\hline 21. & & Tembakau & Nicotiana tabacum $\mathrm{L}$. \\
\hline 22. & & Bawang Putih & Allium sativum $\mathrm{L}$. \\
\hline 23. & & Jarak Jawa & Ricinus communis $\mathrm{L}$. \\
\hline 24. & & Jambe & Areca catechu $\mathrm{L}$. \\
\hline 25. & & Jahe Jawa & Zingiber officinale \\
\hline 26. & Cough reliever & Poo Lanang / Wedok & Eucalyptus globulus Labill. \\
\hline 27. & & Pulosari & Alyxia reinwardtii \\
\hline 28. & & Sempretan & Eupatorium sp. \\
\hline 29. & & Adas & Foeniculum vulgare Mill. \\
\hline 30. & & Asam & Cryptocoryne pontederiifolia Schott. \\
\hline 31. & & Bawang Prei & Allium fistulosum \\
\hline 32. & & Cimplukan & Physalis peruviana $\mathrm{L}$. \\
\hline 33. & & Calingan / Pagan & Rubus alpestris Hook.f. \\
\hline 34. & & Jae Wono & Zingiber sp. \\
\hline 35. & & Jeruk Nipis & Citrus aurantifolia \\
\hline
\end{tabular}




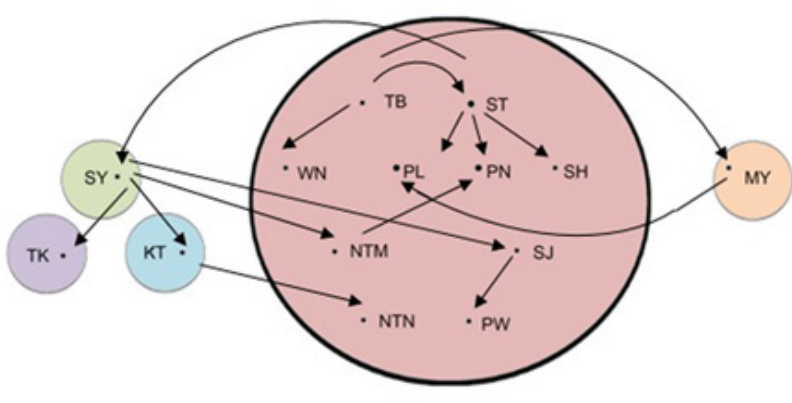

ए: Farmer $\square$ : Forestry Dept. pensionary $\square$ : Trader

Figure 2: Sample map of the respondents.

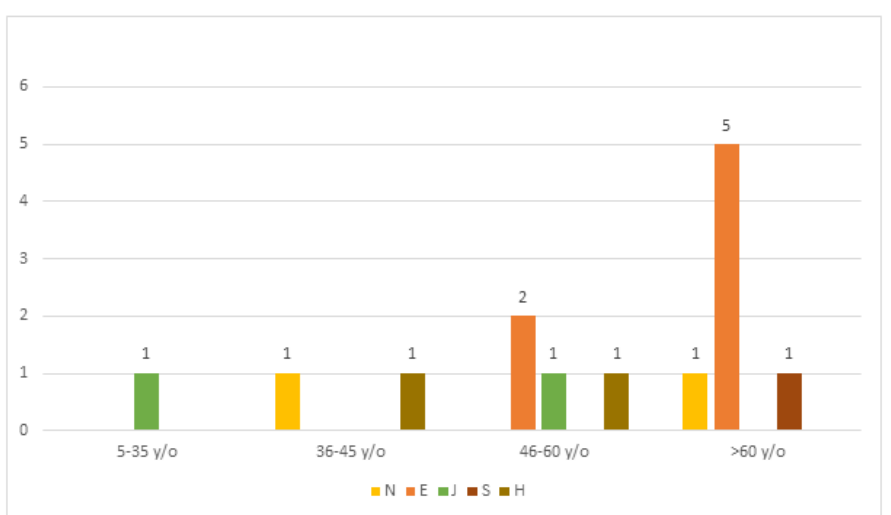

Figure 3: Age and education distribution among the respondents. $\mathrm{N}=$ No Educational background; $\mathrm{E}=$ Finished at elementay school; $\mathrm{J}=$ Finished at junior high school; $\mathrm{S}=$ Finished at senior high school; $\mathrm{H}=$ Finished at higher education level

issue, it seemed that transferring the knowledge down to the younger generation remains a challenge for the Tengger people.

\section{The Medicinal plants}

The plants were spread into 24 families. There were 2 plants that belonged to the family Asteraceae, Euphorbiaceae, Liliaceae, Myrtaceae, Poaceae, Rosaceae, Solanaceae, and Zingiberaceae. The other plants belonged to the family Agaricaceae, Apiaceae, Apocynaceae, Araceae, Arecaceae, Basellaceae, Casuarinaceae, Clusiaceae, Compositae, Equisetaceae, Lauraceae, Melastomataceae, Mimosaceae, Piperaceae, Plantaginaceae, and Rutaceae. There were various parts of the plants used as traditional medicine by The Tengger. The leaf is the most frequent part used for medicine $(58.3 \%)$, the other parts were fruit (13.9\%), root (11.1\%), sap $(8.3 \%)$, whole parts $(8.3 \%)$, seed, nut, rhizome, and bulb (5.5\%), flower, stalk (mushroom), rind, stem, and stem bark, (2.7\%). The Tengger also uses mixtures of some parts of plants for medication, there were 4 mixtures noted in this research. Those parts of the plants are prepared mostly in the form of decoction or concoction (36.1\%) and then used orally. Other preparation methods were brewing, pounding, or straightly applied by eaten or smeared. The regimentation of the plants for the treatments varied and some of the respondents had difficulties in specifying the information needed. Most of the duration of the treatments were 1 to 3 days.

$81.25 \%$ of 32 species were reported in the literature to have antimicrobial activities. The authors also determined the information about other uses of the plants, whether medical or non-medical. The results showed that $77.8 \%$ of the plants possessed other medical uses, some of them were mentioned to possess three other medical uses or even more, which were sempretan, menjari, adas, and cimplukan. $30.5 \%$ of the plants were utilized by The Tengger for non-medical uses such as food and beverage, building material, firewood, ceremonial plant, and animal feed. Some of the plants (55.5\%) also had economical value. This information was gained by asking whether the respondents had any experience in trading the plants or recognize other residents trade the plants. The price of the economically valuable plants was in wide variation, it depends on the availability of the plants (Table 2).

\section{The Indices}

The indices describe how reliable information is confirmed by the community. It measures the level of agreement among the respondent, about the information related to the usage of medicinal plants. The result showed that 4 species were well recognized as medicinal plants by $\geq 70 \%$ of respondents, which were Foeniculum vulgare, Prunus persica, Eupatorium sp., and Astronia macrophylla L. The UVI values showed that among those four plants Eupatorium sp. (sempretan) had the most indication of medical usage (11), compared to Foeniculum vulgare (8), Astronia macrophylla L. (7), and Prunus persica (2). Meanwhile, the FL index showed that among those 4 plants, Foeniculum vulgare, Prunus persica, and Astronia macrophylla L. were well known for their specific medicinal use which were cough remedy and anti-diarrhea. While there were only $41.7 \%$ of respondents agreed that Eupatorium sp. were plant used for wound remedy. Nevertheless, some plants were poorly recognized as medicinal plants such as Equisetum ramosissimum, Albizia lophanta, Euphorbia pulcherrima, Cassuarina equisetifolia, Psidium guajava, Cynodon dactylon, and Areca catechu. Generally, the plants were recognized by their vernacular name, which showed that the knowledge of the plants was less affected by any influence outside the local environment, as can be seen from the KVI values. The more detailed results are shown in Table 3.

\section{DISCUSSION}

The knowledge of medicinal plants is distributed in a certain gender, ages, occupations, and education level. Interestingly, only men are recognized as having knowledge about medicinal plants. It seemed that the men of Tengger have a unique standing in society. This finding is the opposite of many other studies, that generally women possess more traditional knowledge especially related to medicinal plants. ${ }^{46,47}$ It is still unclear whether the knowledge of medicinal plants is passed down to men only or not. It can be assumed that health and the healing process are considered as a spiritual-related matter, and as most local wisdom in Indonesia, only men can be chosen as the spiritual leader. However, it is an interesting issue to be further explored regarding the need for medicinal plant knowledge conservation.

Most of the respondents were older than 60 years old, and the second most respondents were aged between 46 and 60 years old. It is common in much rural society, that elders tend to know more about traditional knowledge compared to the younger one. ${ }^{48,49}$ Lesser knowledge in the younger population can be caused by the reason that younger people of Tengger are relatively more receptive to modern medication than traditional medication of their elders. This pattern of socio-cultural phenomena is also reported in other communities across the world. ${ }^{50-52}$ On the other hand, there seemed no correlation between education level and knowledge about medicinal plants. People who are recognized to have knowledge of medicinal plants have various levels of formal education level. This finding is not surprising since traditional knowledge has been a context of cultural aspect. Thus the length of time spent in 
Table 2: Medicinal plants information.

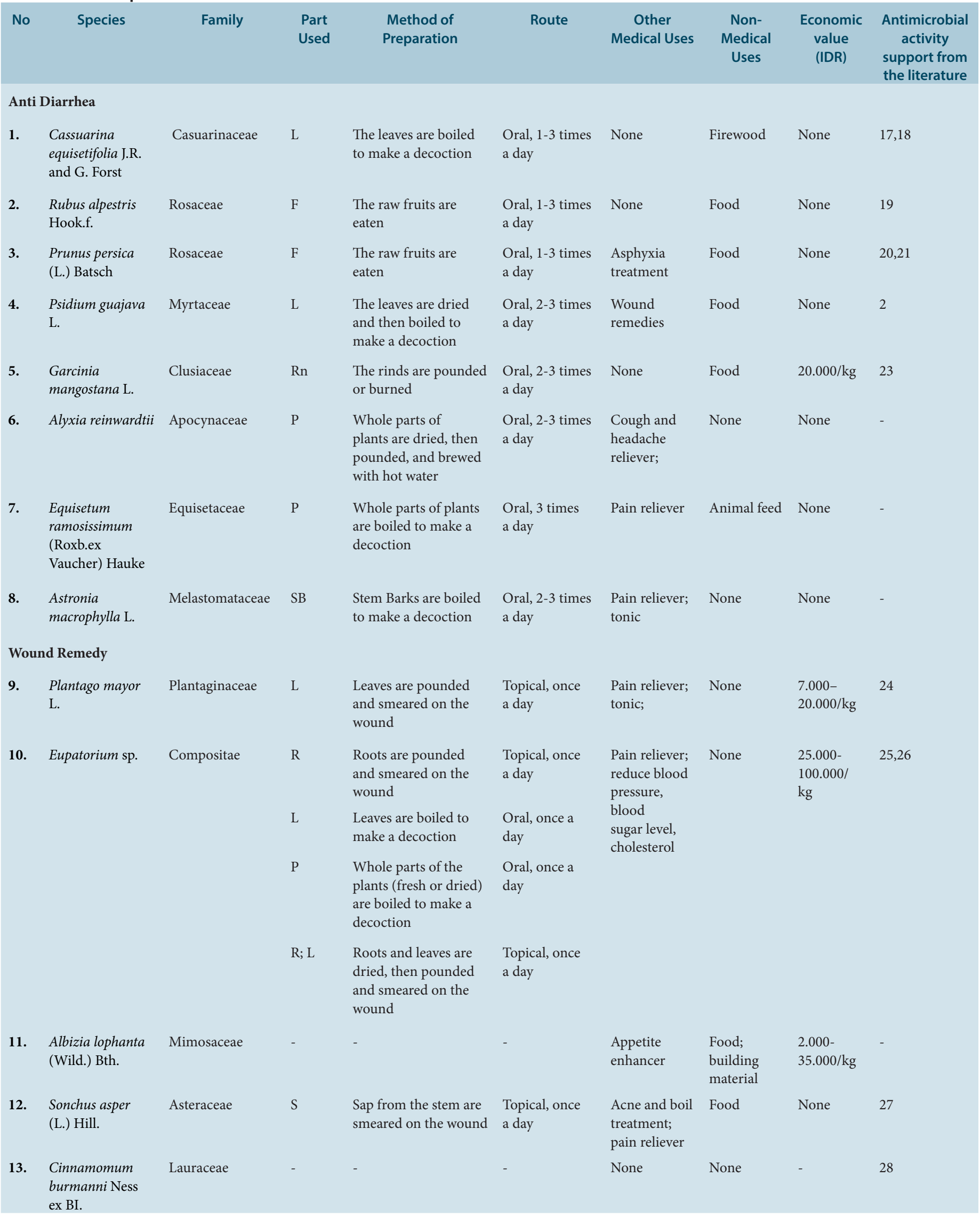




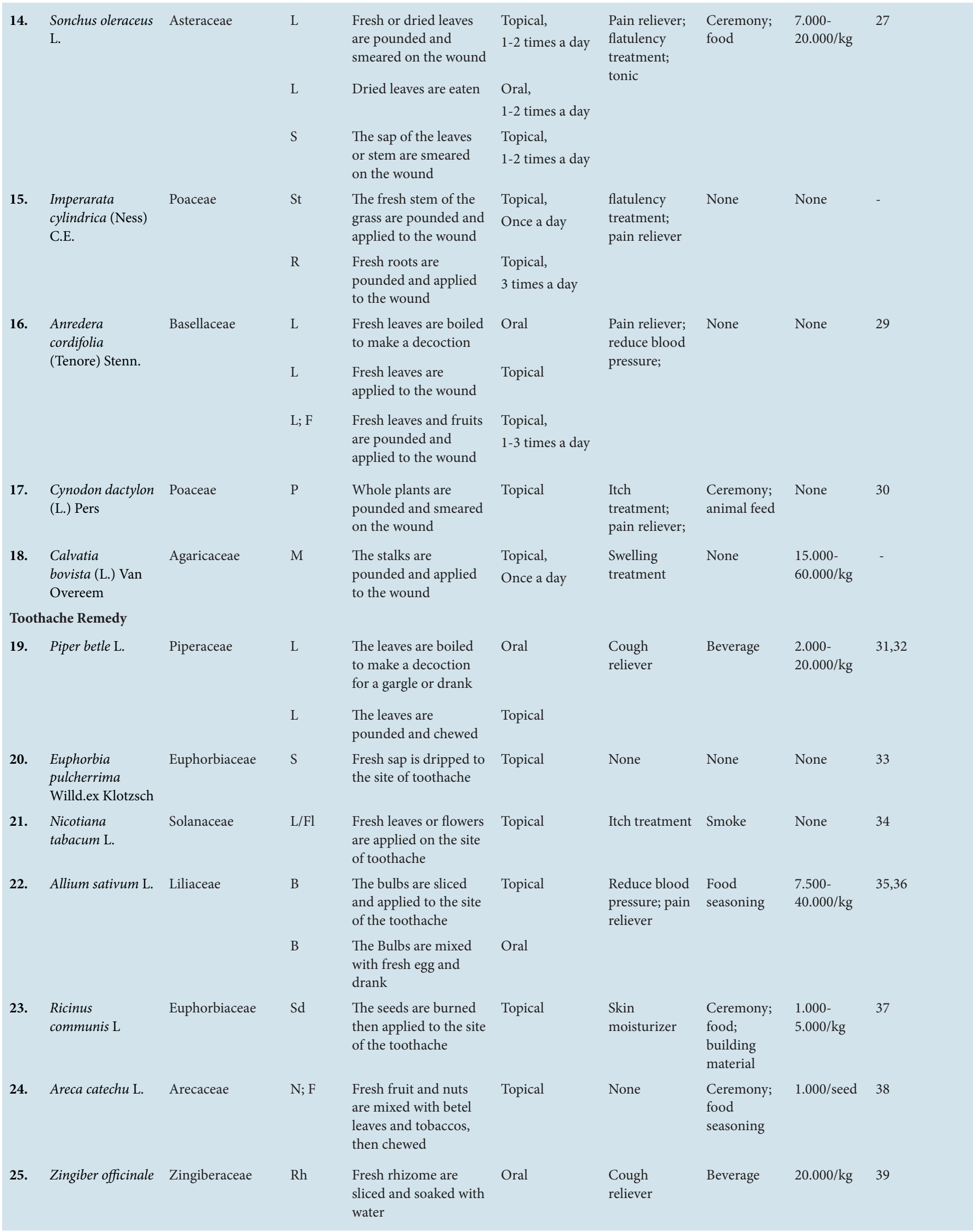




\begin{tabular}{|c|c|c|c|c|c|c|c|c|}
\hline \multicolumn{9}{|c|}{ Cough Reliever } \\
\hline 26. & $\begin{array}{l}\text { Eucalyptus } \\
\text { globulus Labill. }\end{array}$ & Myrtaceae & $\mathrm{L}$ & $\begin{array}{l}\text { Fresh leaves are } \\
\text { poured with boiled } \\
\text { water }\end{array}$ & Oral & $\begin{array}{l}\text { Stomachache } \\
\text { and headache } \\
\text { reliever }\end{array}$ & None & 40 \\
\hline \multirow[t]{2}{*}{28.} & Eupatorium sp. & Compositae & $\mathrm{R}$ & $\begin{array}{l}\text { Fresh roots are dried } \\
\text { then boiled with water } \\
\text { to make a decoction }\end{array}$ & Oral & $\begin{array}{l}\text { Reduce blood } \\
\text { pressure and } \\
\text { sugar level }\end{array}$ & $\begin{array}{l}50.000- \\
100.000 / \\
\mathrm{kg}\end{array}$ & 25,26 \\
\hline & & & $\mathrm{L}$ & $\begin{array}{l}\text { Fresh leaves are eaten } \\
\text { or can be mixed with } \\
\text { adas or menjari and } \\
\text { boiled to make a } \\
\text { concoction. }\end{array}$ & Oral & & & \\
\hline 30. & $\begin{array}{l}\text { Cryptocoryne } \\
\text { pontederiifolia } \\
\text { Schott. }\end{array}$ & Araceae & $\mathrm{L}$ & Fresh leaves are eaten & Oral & None & $\begin{array}{l}1.000- \\
5.000 / \mathrm{kg}\end{array}$ & - \\
\hline 31. & Allium fistulosum & Liliaceae & $\mathrm{P}$ & $\begin{array}{l}\text { The whole plant is } \\
\text { burned and eaten }\end{array}$ & Oral & $\begin{array}{l}\text { flu reliever; } \\
\text { sore throat } \\
\text { treatment }\end{array}$ & $\begin{array}{l}4.000- \\
10.000 / \mathrm{kg}\end{array}$ & 42 \\
\hline 34. & Zingiber sp & Zingiberaceae & $\mathrm{Rh}$ & $\begin{array}{l}\text { Rhizomes are boiled } \\
\text { with water }\end{array}$ & Oral & $\begin{array}{l}\text { Stomachache, } \\
\text { headache } \\
\text { treatment }\end{array}$ & $\begin{array}{l}75.000- \\
150.000 / \\
\mathrm{kg}\end{array}$ & 39 \\
\hline 35. & $\begin{array}{l}\text { Citrus } \\
\text { aurantifolia }\end{array}$ & Rutaceae & $\mathrm{F}$ & $\begin{array}{l}\text { Fresh fruits are } \\
\text { squeezed and drank }\end{array}$ & Oral & None & $\begin{array}{l}5.000- \\
15.000 / \mathrm{kg}\end{array}$ & 45 \\
\hline
\end{tabular}

the classroom will not affect the quality of traditional knowledge. In other studies, the results even showed a contrary, where the length of the formal study had a negative correlation with the possession of traditional knowledge. .33,54 $^{3}$

Indexation will help in quantifying the potential of a medicinal plant. In this study, the value of ethnobotanical richness (ER) shows how much a plant is known for its medical benefits. The value of $E R=1$ means that all respondents are aware that these particular medicinal plants have medical benefits. The Use Value Index (UVI) and Fidelity Level (FL) values are correlated with ER. The greater the value of UVI means the more medical benefits mentioned by the respondents. But the small UVI value does not mean that the plant's potential is getting lower, it is actually possible that all respondents only recognize a fewer number of medical benefits from particular medicinal plants. In such cases, it can be interpreted that the value of medical benefits from plants is more specific. A high FL value indicates the higher potential of the plant, even though it can be caused by the small number of respondents who recognize the medical benefits of a plant. Meanwhile, the value of KVI shows whether knowledge of medicinal plants possessed by respondents is obtained from within or outside their environment. Analysis of four indices indicated that the conformity among respondents about the use of medicinal plants was weak. The ER values described that there were only 4 plants that were recognized by more than $70 \%$ of respondents as medicinal plants, which were Foeniculum vulgare, Prunus persica, Eupatorium sp., and Astronia macrophylla L. Among those 4 plants, Prunus persica has the most interesting indices profile for its low UVI score. The value shows that Prunus persica has the most specific usage for medicinal purposes, which is anti-diarrhea. Several studies support the claim for its antibacterial property. On the contrary, there were no studies found on a literature survey that reported anti-bacterial activity of Astronia macrophylla L. It is challenging to explore the plant further 
Table 3: Medicinal plants indexations.

\begin{tabular}{|c|c|c|c|c|c|}
\hline No. & Species & ER & UVI & $\mathrm{FL}$ & KVI \\
\hline \multicolumn{6}{|c|}{ Anti Diarrhea } \\
\hline 1. & Cassuarina equisetifolia J.R. and G. Forst & 0.143 & 0.500 & 1 & 0.929 \\
\hline 2. & Rubus alpestris Hook.f. & 0.571 & 0.250 & 1 & 1 \\
\hline 3. & Prunus persica (L.) Batsch* & 0.857 & 0.167 & 1 & 1 \\
\hline 4. & Psidium guajava $\mathrm{L}$. & 0.143 & 1.500 & 0.500 & 0.643 \\
\hline 5. & Garcinia mangostana $\mathrm{L}$. & 0.214 & 0.333 & 1 & 1 \\
\hline 6. & Alyxia reinwardtii & 0.429 & 0.833 & 0.333 & 0.929 \\
\hline 7. & Equisetum ramosissimum (Roxb.ex Vaucher) Hauke & 0.071 & 2 & 1 & 0.929 \\
\hline 8. & Astronia macrophylla L.* & 0.786 & 0.636 & 0.818 & 0.929 \\
\hline \multicolumn{6}{|c|}{ Wound Remedy } \\
\hline 9. & Plantago mayor $\mathrm{L}$. & 0.500 & 1.143 & 0.286 & 1 \\
\hline 10. & Eupatorium sp. ${ }^{*}$ & 0.857 & 0.917 & 0.417 & 1 \\
\hline 11. & Albizia lophanta (Wild.) Bth. & 0.071 & 1 & 0 & 0.857 \\
\hline 12. & Sonchus asper (L.) Hill & 0.357 & 1.400 & 0.400 & 0.643 \\
\hline 13. & Cinnamomum burmanni Ness ex BI. & 0.214 & 0.667 & 0 & 0.500 \\
\hline 14 & Sonchus oleraceus L. & 0.643 & 1 & 0.555 & 1 \\
\hline 15. & Imperarata cylindrica (Ness) C.E. & 0.643 & 0.889 & 0.333 & 0.929 \\
\hline 16. & Anredera cordifolia (Tenore) Stenn. & 0.500 & 0.714 & 0.429 & 0.643 \\
\hline 17. & Cynodon dactylon (L.) Pers & 0.143 & 2 & 0.500 & 0.929 \\
\hline 18. & Calvatia bovista (L.) Van Overeem & 0.429 & 0.833 & 0.333 & 1 \\
\hline \multicolumn{6}{|c|}{ Cough Reliever } \\
\hline 19. & Piper betle $\mathrm{L}$. & 0.428 & 1.166 & 0.333 & 0.785 \\
\hline 20. & Euphorbia pulcherrima Willd.ex Klotzsch & 0.071 & 1 & 1 & 0.571 \\
\hline 21. & Nicotiana tabacum L. & 0.285 & 0.500 & 0.750 & 0.929 \\
\hline 22. & Allium sativum $\mathrm{L}$. & 0.428 & 1.166 & 0.333 & 1 \\
\hline 23. & Ricinus communis $\mathrm{L}$. & 0.285 & 1 & 0.50 & 1 \\
\hline 24. & Areca catechu $\mathrm{L}$. & 0.143 & 0.500 & 1 & 0.929 \\
\hline 25. & Zingiber officinale & 0.428 & 0.333 & 0 & 0.929 \\
\hline \multicolumn{6}{|c|}{ Tooth Ache Remedy } \\
\hline 26. & Eucalyptus globulus Labill. & 0.210 & 1.670 & 0.330 & 0.210 \\
\hline 27. & Alyxia reinwardtii & 0.500 & 0.710 & 0.710 & 0.930 \\
\hline 28. & Eupatorium sp. & 0.640 & 1.220 & 0.570 & 1 \\
\hline 29. & Foeniculum vulgare Mill.* & 1 & 0.570 & 1 & 1 \\
\hline 30. & Cryptocoryne pontederiifolia Schott. & 0.071 & 1 & 1 & 0.860 \\
\hline 31. & Allium fistulosum & 0.430 & 0.500 & 1 & 1 \\
\hline 32. & Physalis peruviana $\mathrm{L}$. & 0.500 & 1.140 & 0.430 & 1 \\
\hline 33. & Rubus alpestris Hook.f. & 0.500 & 0.860 & 0.140 & 0.930 \\
\hline 34. & Zingiber sp & 0.430 & 1 & 0.500 & 0.860 \\
\hline 35. & Citrus aurantifolia & 0.290 & 0.250 & 1 & 0.640 \\
\hline
\end{tabular}

since the indices values showed a strong consensus among respondents for the use of Astronia macrophylla L.

\section{CONCLUSION}

Even though there were many plant species were mentioned by the Tengger People to have medical properties, this study showed that only a few of them were agreed communally. This wide variation of information can be caused by various factors that needed to be studied more in-depth. Nevertheless, there were four plants that were highly recognized by the Tengger people as medicinal plants, that is need to be further explored for their antimicrobial properties, among them Prunus persica and Astronia macrophylla L. were the most interesting ones. Several studies supported the claim, however, more in-depth laboratory researches are needed to discover substances that are potential as an antibacterial lead compound. 


\section{ACKNOWLEDGEMENT}

Thanks are expressed to the people of Tengger and authorities of Ngadas Village who kindly supported this research and contributed their invaluable knowledge, and to the Faculty of Medicine of Brawijaya University for its support so that this research could be carried out.

\section{CONFLICT OF INTEREST}

The authors declare no conflict of interest.

\section{ABBREVIATIONS}

ER: Ethnobotanical Richness; UVI: Use Value Index; FL: Fidelity Level; KVI: Knowledge Value Index; L: Leaf; F: Fruit; Fl: Flower; R: Root; Rn: Rind; Rh: Rhizome; P: Whole Plant; S: Sap; Sd: Seed; N: Nut; St: Stem; SB: Stem Bark; B: Bulb; M: Mushroom.

\section{REFERENCES}

1. Fabricant DS, Farnsworth NR. The value of plants used in traditional medicine for drug discovery. Environ Health Perspect. 2001;109(suppl 1):69-75.

2. Albuquerque DUP, Medeiros DPM, Almeida DALS, Monteiro JM, Neto EMDFL, Melo DJG, et al. Medicinal plants of the caatinga (semi-arid) vegetation of $\mathrm{NE}$ Brazil: A quantitative approach. J Ethnopharmacol. 2007;114(3):325-54.

3. Na'im A, Syaputra H. Kewarganegaraan, suku bangsa, agama, dan bahasa sehari-hari penduduk Indonesia: Hasil sensus penduduk. 2010. Jkt BPS. 2011.

4. Murniningtyas E, Darajati WS. Sumardja E. Indonesian biodiversity strategy and action plan 2015-2020. Kementerian Perencanaan Pembangunan Nasional. 2016.

5. Behera SK, Misra MK. Indigenous phytotherapy for genito-urinary diseases used by the Kandha tribe of Orissa, India. J Ethnopharmacol. 2005;102(3):31925.

6. Bussmann RW, Sharon D. Traditional medicinal plant use in Northern Peru: Tracking two thousand years of healing culture. J Ethnobiol Ethnomedicine. 2006;2(1):1-18

7. Kumar A, Pandey VC, Tewari DD. Documentation and determination of consensus about phytotherapeutic veterinary practices among the Tharu tribal community of Uttar Pradesh, India. Trop Anim Health Prod. 2012;44(4):863-72.

8. Stibbe DG, Uhlenbeck UM. Tengger, Encyclopedie van Nederlandch-Indie. Leiden. 1921.

9. Batoro J. Etnobiologi Masyarakat Tengger di Bromo Tengger Semeru Jawa Timur. Phd Thesis. Inst Pertan Bogor Sekol Pasca Sarj. 2012.

10. Batoro J, Siswanto D. Ethnomedicinal survey of plants used by local society in Poncokusumo district, Malang, East Java Province, Indonesia. Asian J Med Biol Res. 2017;3(2):158-67.

11. Ali K, Khan N, Rahman I-U, Khan W, Ali M, Uddin N, et al. The ethnobotanical domain of the Swat Valley, Pakistan. J Ethnobiol Ethnomedicine. 2018;14(1):115.

12. Pemerintah Kabupaten Malang Desa Wisata Ngadas, Poncokusumo. 2017. http://www.malangkab.go.id/site/read/detail/296/desa-wisata-ngadasponcokusumo.html

13. Begossi A. Use of ecological methods in ethnobotany: Diversity indices. Econ Bot. 1996:50(3):280-9.

14. Phillips O, Gentry AH. The useful plants of Tambopata, Peru: I. Statistical hypotheses tests with a new quantitative technique. Econ Bot. 1993;47(1):1532.

15. Friedman J, Yaniv Z, Dafni A, Palewitch D. A preliminary classification of the healing potential of medicinal plants, based on a rational analysis of an ethnopharmacological field survey among Bedouins in the Negev Desert, Israel. J Ethnopharmacol. 1986;16(2-3):275-87.

16. Camejo-Rodrigues J, Ascensao L, Bonet MÀ, Valles J. An ethnobotanical study of medicinal and aromatic plants in the Natural Park of "Serra de São Mamede" (Portugal). J Ethnopharmacol. 2003;89(2-3):199-209.

17. Gumgumjee NM, Hajar AS. Antimicrobial efficacy of Casuarina equisetifolia extracts against some pathogenic microorganisms. J Med Plants Res. 2012;6(47):5819-25

18. Essien EE, Newby JM, Walker TM, Ogunwande IA, Setzer WN, Ekundayo O. Essential oil constituents, anticancer and antimicrobial activity of Ficus mucoso and Casuarina equisetifolia leaves. Am J Essent Oils Nat Prod. 2016;4:1-6.

19. Bakar AMF, Ismail NA, Isha A, Ling MAL. Phytochemical composition and biological activities of selected wild berries (Rubus moluccanus L., $R$ fraxinifolius Poir., and $R$. alpestris Blume). Evid Based Complement Alternat Med. 2016;2016.

20. Belhadj F, Somrani I, Aissaoui N, Messaoud C, Boussaid M, Marzouki MN. Bioactive compounds contents, antioxidant and antimicrobial activities during ripening of Prunus persica L. varieties from the North West of Tunisia. Food Chem. 2016;204:29-36.

21. Edrah S, Alafid F, Kumar A. Preliminary phytochemical screening and antibacterial activity of Pistacia atlantica and Prunus persica plants of Libyan origin. Int J Sc Res. 2013;4(2):1552-5.

22. Biswas B, Rogers K, McLaughlin F, Daniels D, Yadav A. Antimicrobial activities of leaf extracts of guava (Psidium guajava L.) on two gram-negative and grampositive bacteria. Int J Microbiol. 2013.

23. Janardhanan S, Mahendra J, Girija AS, Mahendra L, Priyadharsini V. Antimicrobial effects of Garcinia mangostana on cariogenic microorganisms. J Clin Diagn Res JCDR. 2017:11(1):ZC19

24. Koohsari H, Ghaemi EA, Sheshpoli MS, Jahedi M, Zahiri M. The investigation of antibacterial activity of selected native plants from North of Iran. J Med Life. 2015;8(Spec Iss 2):38

25. Penna CA, Marino S, Gutkind GO, Clavin M, Ferraro G, Martino V. Antimicrobia activity of Eupatorium species growing in Argentina. J Herbs Spices Med Plants. 1998;5(2):21-8

26. Sobrinho ACN, Morais DSM, Souza DEB, Fontenelle DSRO. The genus Eupatorium L.(Asteraceae): A review of their antimicrobial activity. J Med Plants Res. 2017;11(3):43-57.

27. Xia DZ, Yu XF, Zhu ZY, Zou ZD. Antioxidant and antibacterial activity of six edible wild plants (Sonchus spp.) in China. Nat Prod Res. 2011;25(20):1893-901.

28. Shan B, CaiYZ, Brooks JD, Corke H. Antibacterial properties and major bioactive components of cinnamon stick (Cinnamomum burmannii): Activity against foodborne pathogenic bacteria. J Agric Food Chem. 2007;55(14):5484-90.

29. Leliqia NPE, Sukandar EY, Fidrianny I. Antibacterial activities of Anredera cordifolia (Ten) V. Steenis leaves extracts and fractions. Asian J Pharm Clin Res. 2017:10(12):10-3.

30. Abdullah S, Gobilik J, Chong KP. In vitro antimicrobial activity of Cynodon dactylon (L.) pers. (bermudas) against selected pathogens. Dev Sustain Chem Bioprocess Technol. 2013;227-37. [cited 2020 Oct 21] Available from: https://doi. org/10.1007/978-1-4614-6208-8_29

31. Sarma C, Rasane P, Kaur S, Singh J, Singh J, Gat $Y$, et al. Antioxidant and antimicrobial potential of selected varieties of Piper betle L.(Betel leaf). An Acad Bras Ciênc. 2018;90(4):3871-8.

32. Akter KN, Karmakar P, Das A, Anonna SN, Shoma SA, Sattar MM. Evaluation of antibacterial and anthelmintic activities with total phenolic contents of Pipe bete/ leaves. Avicenna J Phytomedicine. 2014;4(5):320.

33. Yakubu Al, Mukhtar MD. In vitro antimicrobial activity of some phytochemical fractions of Euphorbia pulcherima L.(Poinsettia). J Med Plants Res. 2011:5(12):2470-5.

34. Ameya G, Manilal A, Merdekios B. In vitro antibacterial activity and phytochemical analysis of Nicotiana tabacum $\mathrm{L}$. extracted in different organic solvents. Open Microbiol J. 2017;11:352

35. Viswanathan V, Phadatare AG, Mukne A. Antimycobacterial and antibacterial activity of Allium sativum bulbs. Indian J Pharm Sci. 2014:76(3):256.

36. Yetgin A, Canlı K, Altuner EM. Comparison of antimicrobial activity of Allium sativum cloves from China and Tasköprü, Turkey. Adv Pharmacol Sci. 2018.

37. Al-Mamun MA, Akter Z, Uddin MJ, Ferdaus K, Hoque KMF, Ferdousi Z, et al. Characterization and evaluation of antibacterial and antiproliferative activities of crude protein extracts isolated from the seed of Ricinus communis in Bangladesh. BMC Complement Altern Med. 2016;16(1):1-10

38. Sarpangala KB, Sarpangala M, Devasya A. Antimicrobial properties of Areca nut, Areca catechu L: A review. Int J Res Ayurveda Pharm. 2017;8(3):8-12

39. Beristain-Bauza SDC, Hernández-Carranza P, Cid-Pérez TS, Ávila-Sosa R, RuizLópez II, Ochoa-Velasco CE. Antimicrobial activity of ginger (Zingiber officinale) and its application in food products. Food Rev Int. 2019;35(5):407-26.

40. Bachir RG, Benali M. Antibacterial activity of the essential oils from the leaves of Eucalyptus globulus against Escherichia coli and Staphylococcus aureus. Asian Pac J Trop Biomed. 2012;2(9):739-42.

41. Ruberto G, Baratta MT, Deans SG, Dorman HD. Antioxidant and antimicrobia activity of Foeniculum vulgare and Crithmum maritimum essential oils. Planta Med. 2000;66(08):687-93.

42. Chang TC, Jang HD, Lin WD, Duan PF. Antioxidant and antimicrobial activities of commercial rice wine extracts of Taiwanese Allium fistulosum. Food Chem. 2016;190:724-9

43. Göztok F, Zengin F. The antimicrobial activity of Physalis peruviana L. Bitlis Eren Univ J SciTechnol. 2013:3(1):15-7.

44. Ertürk Ö, Ayvaz CM, Can Z, Karaman Ü, Korkmaz K. Antioxidant, antimicrobia activities and phenolic and chemical contents of Physalis peruviana $\mathrm{L}$. from Trabzon, Turkey. Indian J Pharm Educ Res. 2017;51(3):213-6.

45. Aibinu I, Adenipekun T, Adelowotan T, Ogunsanya T, Odugbemi T. Evaluation of the antimicrobial properties of different parts of Citrus aurantifolia (lime fruit) as used locally. Afr J Tradit Complement Altern Med. 2007;4(2):185

46. Quinlan MB, Quinlan RJ. Modernization and medicinal plant knowledge in a Caribbean horticultural village. Med Anthropol Q. 2007;21(2):169-92

47. Voeks RA, Leony A. Forgetting the forest: Assessing medicinal plant erosion in eastern Brazil. Econ Bot. 2004;58(1):S294-306. 
48. Merétika AHC, Peroni N, Hanazaki N. Local knowledge of medicinal plants in three artisanal fishing communities (Itapoá, Southern Brazil), according to gender, age, and urbanization. Acta Bot Bras. 2010;24(2):386-94.

49. Case RJ, Pauli GF, Soejarto DD. Factors in maintaining indigenous knowledge among ethnic communities of Manus Island. Econ Bot. 2005;59(4):356-65.

50. Figueiredo GM, Leitao-Filho HF, Begossi A. Ethnobotany of Atlantic forest coastal communities: II. Diversity of plant uses at Sepetiba Bay (SE Brazil). Hum Ecol. 1997;25(2):353-60

51. Matavele J, Habib M. Ethnobotany in Cabo Delgado, Mozambique: Use of medicinal plants. Environ Dev Sustain. 2000;2(3):227-34.
52. Weckmüller H, Barriocanal C, Maneja R, Boada M. Factors affecting traditional medicinal plant knowledge of the Waorani, Ecuador. Sustainability. 2019;11(16):4460.

53. Saynes-Vásquez A, Caballero J, Meave JA, Chiang F. Cultural change and loss of ethnoecological knowledge among the Isthmus Zapotecs of Mexico. J Ethnobiol Ethnomedicine. 2013;9(1):1-10.

54. Sternberg RJ, Nokes C, Geissler PW, Prince R, Okatcha F, Bundy DA, et al. The relationship between academic and practical intelligence: A case study in Kenya. Intelligence. 2001;29(5):401-18.

Article History: Submission Date : 09-03-2021; Revised Date : 06-04-2021; Acceptance Date : 04-05-2021.

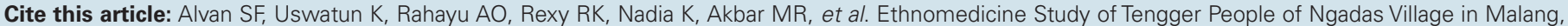
East Java, Indonesia: In Search of Antimicrobial Plants. J Young Pharm. 2021;13(2):97-106. 